\title{
AN INITIAL Review OF Biodiversity Reporting BY SOUTH AFriCAN CORPORATES: THE CASE OF THE FOOD AND Mining SECTORS
}

Hafsa Mansoor and Warren Maroun

School of Accountancy, University of the Witwatersrand

Accepted: August 2016

\begin{abstract}
The purpose of this study is to examine to what extent South African companies listed on the local stock exchange in the mining and food producer and retail sectors are including biodiversity-related issues in their integrated and sustainability reports. The study employs established biodiversity reporting frameworks for gauging changes in the frequency of disclosures from 2011 to 2013 and determining if biodiversity information is being included in either the integrated or sustainability reports of the companies under review. Consistent with the findings of a special edition of Accounting, Auditing and Accountability Journal (AAAJ), the research finds few examples of detailed reporting on biodiversity issues. This is despite the fact that South Africa has a well-established code of corporate governance, a long history of including non-financial information in corporate reports and is an advocate of the integrated reporting movement. The study calls into question the sincerity of companies in the two sectors under review when it comes to providing balanced accounts of their management of non-financial capital as recommended by the country's codes on governance and the International Integrated Reporting Council.
\end{abstract}

Key words: biodiversity, food industry, mining industry, South Africa, sustainability

JEL: M1, 4

\section{$1 \quad$ Introduction ${ }^{1}$}

Species are becoming extinct 1000 times faster than indicated by the historical trends (Millennium Ecosystem Assessment, 2005; Rimmel \& Jonäll, 2013), largely as a result of climate change and, interconnected with this, human activity (Van Liempd \& Busch, 2013). A recently published special edition of Accounting, Auditing and Accountability Journal reiterates the massive risk posed by habitat loss, changing weather patterns and mass extinction of species (Jones \& Solomon, 2013). Nevertheless, what little research has been done on how organisations are dealing with these challenges finds that many companies in some of the world's leading economies are marginalising biodiversity reporting (Grabsch, Jones \& Solomon, 2012; Rimmel \& Jonäll, 2013; Van Liempd \& Busch, 2013). This is true even after the release of scientific evidence pointing to environmental catastrophe (Intergovernmental Panel on Climate Change, 2013 [IPCC], 2013) and the inevitable social, economic and political turmoil which will result.

In this context, this research explores the extent of biodiversity reporting by two highbiodiversity risk sectors in South Africa. It gauges changes in disclosure frequencies from 2011 to 2013 by a sample of mining companies, food producers and retailers and determines if biodiversity-related information is being communicated in the primary report to stakeholders (the integrated report) or in a complementary sustainability report. This is done using a content analysis of integrated and sustainability reports and the disclosure frameworks provided by Van Liempd and Busch (2013), Grabsch et al. (2012) and the Global Reporting Initiative (GRI, 2007). In keeping with an interpretive tradition, the research also offers possible reasons for observed disclosure trends.

The above-mentioned disclosure frameworks are selected because they provide an outline of biodiversity reporting which is not specific to particular regions (Jones \& Solomon, 2013). As a result, they are useful for evaluating changing reporting trends in different industry sectors and geographical locations. At the same time, the chosen frameworks have already been applied and 
tested in different settings. This means that they constitute a reasonable basis for carrying out the analysis in this paper and avoid the need to develop an alternate and subjective reporting typology which may not be directly comparable with prior studies.

The research concentrates specifically on biodiversity disclosures by South African companies because, while there has been at least some work on biodiversity reporting in the European Union (E.U) and New Zealand (for examples see Jones, 1996; Gray, 2006; Grabsch et al., 2012; Jones \& Solomon, 2013; Samkin, Schneider \& Tappin, 2014), there is nothing from a South African perspective. This is despite the fact that the country is dependent on its natural and environmental resources for economic growth and boasts one of the world's richest collections of flora and fauna (Department of Environmental Affairs and Tourism (DEAT), 2013). South Africa's codes of corporate governance are also well-established (Solomon, 2010; Maroun, Coldwell \& Segal, 2014) and deal specifically with the importance of non-financial reporting, including environmental sustainability (Institute of Directors in Southern Africa [IOD], 2009). What is more, in 2010, the country's stock exchange was the first in the world to introduce a requirement for listed companies to prepare an integrated report (which provides a balanced account of financial and non-financial metrics) or justify the reasons for not doing so (Johannesburg Stock Exchange [JSE], 2013; Solomon \& Maroun, 2012). In this way, South Africa - despite being a developing economy - is an example of a jurisdiction where non-financial reporting and corporate governance is well developed (see, for example, De Villiers \& Barnard, 2000; Integrated Reporting Committee of South Africa, 2011; Solomon \& Maroun, 2012; Carels, Maroun \& Padia, 2013; Maroun et al., 2014) and where one may reasonably expect to find more emphasis on biodiversity reporting.

Examining biodiversity disclosures of some of South Africa's largest organisations, addresses the call for additional research from different settings to provide a better assessment of the international effort to report on significant environmental challenges (Jones \& Solomon, 2013). At the same time, this study makes an important contribution by assessing the state of integrated reporting by South African organisations with a specific focus on biodiversity issues.

The remainder of this paper is structured as follows: Section 2 discusses biodiversity reporting and the relevance of biodiversity management (the means of managing areas to restore or conserve ecological services and biological resources) in South Africa (Samkin et al., 2014). The intention is not to provide a comprehensive assessment of accounting for biodiversity but to use some of the latest research to develop a disclosure matrix to analyse South African integrated and sustainability reports, as explained in Section 3. Section 4 discusses the method. Section 5 presents results and Section 6 provides an analysis of findings. Section 7 concludes.

\section{The nature of biodiversity and biodiversity reporting}

The GRI is an independent international organisation which aims to assist companies to understand and communicate their impact on sustainability issues, including different social challenges, climate change and habitat destruction (GRI, 2007). As there is no generally-accepted framework on biodiversity management, the guidance provided by the GRI is also used to inform reporting on biodiversity issues (Rimmel \& Jonäll, 2013)

According to the GRI (2007, p. 11):

Biodiversity is the variability among living organisms from all sources, including, inter alia, terrestrial, marine and other aquatic ecosystems and the ecological complexes of which they are part, this includes diversity within species, between species and of ecosystems.

'Biodiversity' can be interpreted in multiple ways but a common feature in all definitions relates to the variety and variability of living organisms, their habitats and biological ecosystems (Kaennel, 1998; Grabsch et al., 2012; Rimmel \& Jonäll, 2013). In essence, biodiversity can be simplified to describe the variety of life on earth (Global Reporting Initiative, 2007; Grabsch et al., 2012).

Historically, organisations adopted an anthropocentric view of biodiversity in terms of which the value of the different species was derived from the contribution of the ecosystem to human 
activity (Grabsch et al., 2012; Jones \& Solomon, 2013). A significant alternate perspective is the deep ecology view in terms of which the value of biodiversity is not considered only according to its contribution to humanity but also from a moral and ethical standpoint (Grabsch et al., 2012; Jones \& Solomon, 2013). Advocates of this theory argue that human beings have a moral obligation to preserve species and maintain the integrity of natural communities (Jones, 2010). This view is consistent with the approach to sustainability advanced by Gray (2010): that natural capital should dominate human-related capital (Grabsch et al., 2012). Ultimately, however, anthropocentrism and non-anthropocentrism both encourage the protection and conservation and maintenance of biodiversity (Jones, 1996; Jones, 2010).

\subsection{South African biodiversity and its importance to the local economy}

South Africa is considered to be the third most biologically diverse country in the world, accommodating between 250000 and 1 million species, many of which are unique to South Africa. As a result, the conservation of the country's biodiversity is considered to be of international importance (DEAT, 1998; Wynberg, 2002) ${ }^{2}$. South Africa contains nine terrestrial biomes and is home to a spectacular variety of ecosystems, including wide diversity in marine and coastal systems (Wynberg, 2002; Turpie, 2003; South African National Biodiversity Institute, 2014).

Biodiversity is closely interwoven in South African society and is an important factor in many of the key economic sectors, such as agriculture and mining (DEAT, 1998). It is estimated that the ecosystem services in South Africa generate approximately 73 billion Rand ${ }^{3}$ per annum, which is equivalent to approximately 7 per cent of the country's GDP (DEAT, 2009). This diversity supports the livelihoods of millions of South Africans and significantly contributes to the country's economy (Wynberg, 2002).

In this context, the DEAT is primarily responsible for biodiversity management. The South African National Biodiversity Institute (SANBI), created as a public entity by the Department of Environmental Affairs to lead and co-ordinate research, assists with monitoring of and reporting on the state of biodiversity in South Africa (Wynberg, 2002; South African National Biodiversity Institute, 2014). SANBI's mission is to promote the sustainable use, conservation and appreciation of the rich biodiversity of South Africa for the benefit of present and future generations (SANBI, 2010). South Africa was also one of the countries that signed the Convention of Biological Diversity which is dedicated to the development and sustainable use of biodiversity (Wynberg, 2002; Global Reporting Initiative, 2007). Nevertheless, South Africa's biodiversity is under great threat (DEAT, 1998).

Agricultural and industrial development has led to the transformation, fragmentation and degradation of natural habitats accelerating at an alarming rate. The increasing human population, as well as unsustainable rates of natural resource consumption, will continue to negatively affect the country's biodiversity (DEAT, 1998; DEAT, 2009). It has been estimated that 15 per cent of South Africa's plant, 14 per cent of bird, 24 per cent of reptile, 18 per cent of amphibian, 90 per cent of mammal and 22 per cent of butterfly species are classified as 'threatened' according to the South African Red Data Book (DEAT, 1998). Existing trends are not expected to improve as the country continues to grapple with its social and economic challenges (DEAT, 1998; DEAT, 2009). This is particularly evident when one considers the local mining and food industries, both of which play an important economic role and create major biodiversity challenges.

It is widely accepted that the operating activities of the South African mining houses have a significant environmental impact. Even where companies are adhering to best environmental practice, there is an inherent risk of habitat loss and the release of pollutants into ecosystems (Department of Environmental Affairs, Department of Minerals and Resources, Chamber of Mines, South African mining and biodiversity forum \& South African National Biodiversity Institute, 2013; Endangered Wildlife Trust, 2015) with the result that, the sector has come under increasing scrutiny from different stakeholders, including some institutional investors 
(International Council on Mining and Metals, 2006; Carels et al., 2013; Atkins \& Maroun, 2014). In order to help mines manage their biodiversity risks, the International Council on Mining and Metals (ICMM), together with the International Union for Conservation of Nature (IUCN), developed a Good Practice Guidance for Mining and Biodiversity to provide the mining sector with an outline of the steps required to improve and implement biodiversity management throughout the life cycle of a mine (International Council on Mining and Metals, 2006). In an attempt to balance economic and biodiversity considerations, the Mining and Biodiversity Guideline: Mainstreaming Biodiversity Mining Sector was jointly created by the SANBI, the Department of Environmental Affairs and the Chamber of Mines as a means to promote economic growth while minimising the effect of mining activities on the ecosystem (Department of Environmental Affairs et al., 2013). The guideline emphasises the value of a risk-based approach to biodiversity and encourages the assessment of biodiversity risk at every level of a mining project. The ultimate aim of the guideline is to integrate relevant biodiversity information into the decision-making process of the companies in the mining sector (Department of Environmental Affairs et al., 2013).

A similar approach has been adopted in the food industry. The SANBI aims to promote sustainable farming practices and works with a number of organisations to promote biodiversity conservation (South African National Biodiversity Institute, 2015). For example, in conjunction with the WWF-SA, SANBI created the Green Choice Living Farms Reference which outlines generic principles and indicators for sustainable farm management in South Africa in order to aid farmers in the implementation of sustainable practices (Scotcher, 2009; SANBI, 2015). Recent projects include: the Conservation Farming Project, the Global Pollination Project and the Honeybee Forage Project, as well as retailer initiatives such as the Woolworths' Farming for the Future programme (South African National Biodiversity Institute, 2015). These initiatives attempt to strike a balance between promoting an industry which makes a significant contribution to economic activity and is at the heart of South Africa's food security with the need to protect against environmental degradation and mitigate biodiversity loss.

\subsection{Reporting on biodiversity}

Efforts have been made internationally through the Global Reporting Initiative and Integrated Reporting Project to cover some aspects of biodiversity (Jones \& Solomon, 2013). In a South African context, the Johannesburg Stock Exchange (JSE) effectively requires companies to prepare an integrated report which addresses how an organisation is managing, inter alia, its environmental and social capital or explain why no such report has been prepared. Compliance would include an integrated assessment of how an organisation is managing various non-financial metrics (including its environmental impact) in order to generate sustainable returns (Solomon \& Maroun, 2012; International Integrated Reporting Council [IIRC], 2013; South African Institute of Chartered Accountants, 2013). As part of this process, the use of the Global Initiative's guidelines for reporting on sustainability issues is recommended (IOD, 2009).

Initial studies have reported an increase in the extent to which listed South African companies are including environmental, social and governance indicators in their primary reports to stakeholders (Hindley \& Buys, 2012; Solomon \& Maroun, 2012; Carels et al., 2013). This has gone hand-in-hand with the number of companies referring explicitly to the GRI's guidelines for reporting sustainability-related issues in their annual or integrated reports (Hindley \& Buys, 2012; Rimmel \& Jonäll, 2013). One aspect of the environmental section of the GRI sustainabilityreporting framework relates to biodiversity. Although 'biodiversity' is a broad concept, with the result that one may argue that many GRI reporting recommendations deal directly or indirectly with this subject, five indicators specifically relate to 'biodiversity' (Global Reporting Initiative, 2007; Rimmel \& Jonäll, 2013). These are summarised in Table 1. 
Table 1

GRI biodiversity indicators

\begin{tabular}{|l|l|}
\hline \multicolumn{1}{|c|}{ Indicator } & \multicolumn{1}{c|}{ Explanation } \\
\hline EN11 (Core) & $\begin{array}{l}\text { Location and size of land owned, leased, managed in, or adjacent to, protected areas and areas of high } \\
\text { biodiversity value outside protected areas. }\end{array}$ \\
\hline EN12 (Core) & $\begin{array}{l}\text { Description of significant impacts of activities, products and services on biodiversity in protected areas } \\
\text { and areas of high biodiversity value outside protected areas. }\end{array}$ \\
\hline EN13 (Additional) & Habitats protected or restored. \\
\hline EN14 (Additional) & Strategies, current actions, and future plans for managing impacts on biodiversity. \\
\hline EN15 (Additional) & $\begin{array}{l}\text { Number of IUCN Red List species and national conservation list species with habitats in areas affected } \\
\text { by operations, by level of extinction risk. }\end{array}$ \\
\hline
\end{tabular}

The extent to which companies have been incorporating the recommended core and additional performance indicators in their integrated, annual or sustainability reports is, however, unclear. The main challenge relating to biodiversity reporting is the uncertainty about the definition of 'biodiversity' and how it should be measured and communicated to stakeholders (Grabsch et al., 2012; Jones \& Solomon, 2013). The GRI and Integrated Reporting Framework cover some aspects of biodiversity (see IIRC, 2013; GRI, 2014) but there is a lack of a generally acceptable framework for reporting on biodiversity-related issues (Grabsch et al., 2012). In addition, while there has been a fair amount of research on non-financial reporting by South African companies (for examples, see De Villiers \& Barnard, 2000; De Klerk \& De Villiers, 2012; Carels et al., 2013; De Villiers, Low \& Samkin, 2014) biodiversity disclosure has been neglected. In this context, the emerging body of research dealing with reporting on biodiversity issues in a European setting is used to provide a frame of reference for analysing biodiversity disclosure by South African corporates.

\subsection{Development of the data collection instrument}

Grabsch et al. (2012) developed theme codes to evaluate the extent of biodiversity disclosures. Biodiversity disclosures were divided into eight categories, namely, (1) scene-setting; (2) speciesrelated; (3) social engagements; (4) stakeholder engagements; (5) performance evaluative data; (6) risk; (7) internal management; and (8) external reporting (Grabsch et al., 2012). Scene-setting encompasses the company's definition of 'biodiversity' and how the company sets the scene for reporting on biodiversity. It is usually associated with a biodiversity mission statement (Grabsch et al., 2012; Van Liempd \& Busch, 2013). Disclosures relating to how many species are present, the types of species present and the efforts made by a company to protect or maintain these species are encompassed by the 'species-related' category (Van Liempd \& Busch, 2013).

Companies often form partnerships with non-profit organisations, universities or governments in their efforts to be regarded as good corporate citizens. Social engagements incorporate the extent of such affiliations and recognisable outcomes. On the other hand, stakeholder engagements relate to any form of engagement a company has had with various stakeholders in terms of biodiversity issues (Grabsch et al., 2012). Companies are also expected to report on their biodiversity performance targets and to provide feedback on their ability to meet such expectations. Included in this assessment are the risks faced in terms of performance and biodiversity in general. This also forms part of the performance data and risk categories (Grabsch et al., 2012; Van Liempd \& Busch, 2013).

Finally, internal management and external reporting refer to the internal action plans of the company in relation to biodiversity and their internal processes to ensure such actions are executed and reported in an appropriate manner, ideally in accordance with accepted reporting frameworks, like the GRI (Grabsch et al., 2012; Van Liempd \& Busch, 2013). Each of these predetermined disclosure categories (per Table 2) serves as disclosure or theme codes (see Section 4) for the purpose of this study. 
Table 2

Summary of disclosure themes

\begin{tabular}{|c|c|}
\hline Codes/themes & Elements \\
\hline 1. Scene - setting & $\begin{array}{l}\text { - Definition } \\
\text { - Mission statement }\end{array}$ \\
\hline 2. Species - related & $\begin{array}{l}\text { - Site-specific } \\
\text { - Specific species } \\
\text { - Surveys } \\
\text { - IUCN red list }\end{array}$ \\
\hline 3. Social and stakeholder engagements ${ }^{4}$ & $\begin{array}{l}\text { - Partnerships } \\
\text { - Awards } \\
\text { - Stakeholder engagements }\end{array}$ \\
\hline 4. Performance evaluations & $\begin{array}{l}\text { - Target performance } \\
\text { - Costs }\end{array}$ \\
\hline 5. Risk & $\begin{array}{l}\text { - Risk } \\
\text { - Risk management } \\
\text { - Incidents } \\
\text { - Materiality }\end{array}$ \\
\hline 6. Internal management & $\begin{array}{l}\text { - Biodiversity action plans } \\
\text { - Biodiversity officer }\end{array}$ \\
\hline 7. External reporting & - GRI and other frameworks \\
\hline
\end{tabular}

As discussed above, the theme codes are obtained directly from the framework used by Grabsch et al. (2012). The 'elements' forming part of each code are obtained from the descriptions of the theme codes provided by Grabsch et al. (2012) and a prior study which explicily applied this framework (Van Liempd \& Busch, 2013).

\section{Prior research and theoretical framework}

\subsection{Environmental reporting and organisational legitimacy}

There is a large body of interpretive research explaining the emergence and development of reporting on environmental issues (see, for example, Gray et al., 1995; Higgins \& Walker, 2012; Tregidga, Milne \& Kearins, 2014). Particularly important for the purpose of this paper is the use of different environmental indicators to appeal to the interest of stakeholders and enhance or maintain the credibility of the reporting entity. This builds on a social constructivist perspective in terms of which contemporary firms are not only dependent on rational structures and operating efficiencies for continued existence but also on the maintenance of public confidence or legitimacy (Meyer \& Rowan, 1977; Suchman, 1995). In other words, modern organisations cannot depend only on generating a profit to justify their continued existence. Their 'social contract' requires them to demonstrate how they are managing pressing environmental issues (see, for example, Gray et al., 1995; IOD, 2009; IIRC, 2013; Atkins \& Maroun, 2015) with the result that reporting on different environmental indicators is often informed by the need to gain, maintain or repair legitimacy.

For example, faced with mounting criticism of environmental track records, additional environmental reporting can be used to signal an awareness of societal concerns and suggest that positive action is being taken in order to maintain claims to legitimacy (De Villiers \& Van Staden, 2006; De Villiers \& Alexander, 2014). In this context, a study of environmental disclosures by BHP found that the company publishes positive social and environmental information in response to unfavourable media attention (Deegan, Rankin \& Tobin, 2002). Patten (1992; 2002) reports similar findings, arguing that the frequency of environmental disclosures included in corporate reports is directly proportional to the perceived importance of the respective environmental issues (see also Brennan \& Merkl-Davies, 2014).

In other words, environmental reporting allows the organisation to appeal to the beliefs or values of important stakeholders, to garner support and to avoid additional scrutiny (Higgins \& Walker, 2012; Tregidga et al., 2014). This type of non-financial reporting can, however, have 
unintended consequences. According to O'Dwyer (2002) additional disclosure has the 'potential to engender rather than diminish societal scepticism in an environment where public pressure is keenly felt by many organisations'. For this reason, companies with high environmental impacts often reduce detailed reporting in an effort to avoid public scrutiny (De Villiers \& Van Staden, 2006; Solomon, Solomon, Joseph \& Norton, 2013). Similarly, companies may rely on a strategy of reporting generic information to limit the possibility of stakeholders reconciling corporate action and rhetoric, identifying shortcomings and withdrawing their support for the organisation (Cho, Laine, Roberts \& Rodrigue 2015; Boiral, 2016). The same logic may apply when considering the emphasis placed on biodiversity reporting as part of the broader sustainability or environmental reporting paradigm.

\subsection{Prior biodiversity reporting studies}

Recent studies conducted on the extent of biodiversity disclosures in Sweden, Denmark, England and Germany found that high environmental impact industries are more likely to include disclosures on biodiversity issues (Grabsch et al., 2012). Reporting is, however, relatively limited and generic (Grabsch et al., 2012; Rimmel \& Jonäll, 2013; Van Liempd \& Busch, 2013). The most common disclosures relate to mission statements, partnerships and the GRI reporting (Grabsch et al., 2012; Van Liempd \& Busch, 2013). On the other hand, performance, internal management and external reporting disclosures were among the lowest scoring categories, suggesting that for many companies biodiversity reporting is still in its infancy. This is supported by the fact that mission statements are often vague and the respective annual or sustainability reports usually lack detailed disclosures that provide meaningful insights into how organisations are defining and managing their biodiversity-related risks (Jones \& Solomon, 2013; Van Liempd \& Busch, 2013).

The direct impact of corporate activity on biodiversity mass, coupled with high public scrutiny, means that companies provide at least some information on biodiversity metrics to secure public confidence (Patten, 2002; Jones \& Solomon, 2013). Managing biodiversity loss is, however, a complex issue with significant operational and financial implications (Sizemore, 2015; Jones \& Solomon, 2013). Consequently, companies limit the extent of reporting in order to avoid stakeholders raising concerns about biodiversity issues which might have gone unnoticed if the information had not been included in the corporate report (De Villiers \& Van Staden, 2006; Boiral, 2016). Similarly, where information is provided, it is often generic. The aim is not necessarily to mislead stakeholders: instead, companies rely on a disconnect between general policy statements about biodiversity loss and details on specific plans and actions which, if scrutinized, could lead to additional difficulties and unexpected challenges to the business operations (see Solomon et al., 2013; Cho et al., 2015). In other words, and as explained by De Villiers and Van Staden (2006: 426), companies 'decrease specific disclosures when they perceive them to be potentially more damaging than helpful to maintain legitimacy'.

The same may be applicable in a South African context. A large body of scientific research confirms that the country's biodiversity is threatened by human activity and that this creates significant challenges for the local economy (Section 2.1). As a result, it would be reasonable to expect local companies - especially those with a high environmental impact - to include detailed information on biodiversity risks and how these are being actively managed (see Patten, 2002). This is especially true given the growing appreciation of the importance of environmental responsibility and awareness. For example, and as discussed in Section 2.1 and 2.2, a number of different environmental groups are highlighting the need for effective management of environmental issues by high environmental impact sectors. This is reinforced by codes on corporate governance which call for detailed reporting on environmental issues including how organisations are managing environmental capital as part of their strategy for generating sustainable returns (IOD, 2009; IIRC, 2013). Finally, there is evidence of non-financial reporting being value-relevant (De Klerk \& De Villiers, 2012) and South African institutional investors 
engaging on suitability-related issues (which would include biodiversity management) as part of a drive to promote responsible and sustainable investment practices (Atkins \& Maroun, 2015).

Nevertheless, there is no guarantee that there have been dramatic changes in corporate reporting on biodiversity issues (see Carels et al., 2013; Atkins \& Maroun, 2014). If South African companies face pressures to maintain legitimacy, it may be the case that biodiversity risks are dealt with by limiting the extent of reporting to generic statements and avoiding detail on specific action plans necessary for tackling this growing environmental challenge.

\section{Method}

Content analysis is used to determine the extent of biodiversity disclosures found in the integrated and sustainability reports of companies included in the JSE's mining and food producer and retail sectors. This method is frequently used to study non-statutory disclosures in corporate reports and involves codification of information found in these reports into predefined categories in order to highlight trends and make inferences (Samkin et al., 2014). In keeping with an interpretive approach, data collection and analysis required detailed involvement by the researchers, with the result that the findings are subjective. Nevertheless, the chosen method was the most appropriate, given the limited research on biodiversity reporting and the need to process information which cannot be objectively measured on a relative scale.

The researchers concentrated on the food and mining industry due to the classification of these as red-zone sectors by the F\&C Asset Management (2004) and the growing awareness of the importance of emerging environmental issues by organisations in these sectors (Section 2.1). The integrated and sustainability reports from 2011 to 2013 of the 10 largest companies (by market capitalisation) per sector were analysed representing 95 per cent of the food producers and retailers and 88 per cent of the mining companies listed on the JSE (see Appendix 1). The sample was based on the assumption that larger organisations have a greater biodiversity impact, attract most attention from stakeholders and have the resources and systems to provide detailed information on biodiversity-related matters ${ }^{5}$ (Rimmel \& Jonäll, 2013; Van Liempd \& Busch, 2013; De Villiers et al., 2014).

The relatively small and unequal samples were not considered a threat to validity or reliability given the exploratory nature of the study and the fact that the intention is not to extrapolate results (Merkl-Davies et al., 2011). In addition, the time-consuming nature of the data collection process means that interpretive text analysis can only be productively applied to smaller samples (ibid).

\subsection{Data sources}

The integrated and sustainability reports dated from 2011 to 2013 were analysed. The 2010 reports were not included in the study as this was the transitional year for the implementation of King-III which formally introduced the concept of 'integrated reporting' to South African corporate governance. In addition, complementary information provided on company websites was not analysed. This was mainly due to the challenge of determining when information had been posted on the respective websites or last updated, making it impossible to track changes over time (Rimmel \& Jonäll, 2013). The research also excluded articles found in the financial or popular press as these are not necessarily prepared by the organisations under review and were not produced as the primary means of communication with stakeholders per King-III (IOD, 2009), the IIRC (2013) and JSE (2013).

\subsection{Data analysis}

Following the same approach as Grabsch et al. (2012) and Van Liempd and Busch (2013), the lead researcher carried out an initial review of the reports of the sample of South African companies to gain a sense of their content and structure (Leedy \& Ormrod, 2013) and the nature of biodiversity disclosures included in the respective documents. For this purpose, a broad definition of 'biodiversity' was applied to interpret companies' reporting on ecosystems, habitats, ecosystem 
services, conservation, preservation, restoration and information on species (Grabsch et al., 2012; Van Liempd \& Busch, 2013). The reports were read and analysed interpretively, drawing out items related to biodiversity. To ensure that all relevant disclosures were identified the lead researcher also searched for keywords which are associated with genetic and eco-systemic biodiversity (adapted from Van Liempd \& Busch, 2013). These include, inter alia, 'biodiversity', 'habitat', 'eco-system', 'conservation', 'species', 'flora', 'fauna', 'wildlife', 'marine' and 'maritime'. For this purpose, the 'text unit of analysis' was at the level of the phrase, clause or theme (Samkin et al., 2014:538).

The identified text units were grouped according to pre-determined theme codes derived from the literature and GRI (as discussed in Section 3). These comprise:

1 Scene-setting.

2 Species-related.

3 Social and stakeholder engagement. ${ }^{6}$

4 Performance evaluation.

5 Risk.

6 Internal management.

7 External reports.

A score of ' 0 ' or ' 1 ' was used to indicate the presence or absence of the respective biodiversitydisclosure metric. A frequency table (according to disclosure theme) was generated to show the extent of biodiversity disclosures for each company for the chosen years (Leedy \& Ormrod, 2013). The scoring process involved some subjectivity and, as a result, the determination of frequency scores by the researchers was reviewed by an independent research assistant. High levels of repetition is also a possibility (Solomon \& Maroun, 2012; Raemaekers, Maroun \& Padia, 2015). To avoid creating the impression that biodiversity-related issues are more extensively discussed than is the case, the researchers assigned a score according only to the occurrence or nonoccurrence of disclosures in specific sections of the reports under review, rather than based on the number of times a specific key word was dealt with in each part of the integrated or satiability reports. It should be noted that, due to the fact that there is no generally acceptable scale for assessing the quality of disclosure, this was not dealt with and is an inherent limitation of the research.

Small sample sizes negated the use of inferential statistics. Instead, disclosure frequencies were analysed using descriptive statistics (Grabsch et al., 2012; Rimmel \& Jonäll, 2013; Van Liempd \& Busch, 2013). The frequency of the biodiversity disclosures per theme was recorded and the cumulative change in disclosure scores was calculated. In addition, the researcher considered changes in the extent to which specific disclosure themes (Table 2) were being included in either the integrated or sustainability report. This approach avoids creating the impression that the researchers are 'measuring' biodiversity disclosures in a positivist sense and provides an easy-tounderstand assessment of the extent to which biodiversity information is being reported.

\section{Preliminary results}

Figures 1 and 2 show the changes in the extent of biodiversity reporting in both integrated and sustainability reports from 2011 to 2013 disaggregated by disclosure or theme code.

As indicated in Figure 1, the disclosure score in the mining sector increases from 124 (2011) to 137 in 2012 followed by a decrease to 130 in 2013 or a net increase of just 5 per cent from 2011 to 2013. Each disclosure theme shows a similar trend with no disclosure accounting for a significant portion of the change in score over the three years. The risk theme accounts for the majority of disclosures (28 per cent) followed by performance evaluation (16 per cent) and species-related information (15 per cent). Disclosure on social engagement ( 9 per cent) and internal management (9 per cent) were the least frequent. 
Figure 1

Total biodiversity disclosure: Mining sector

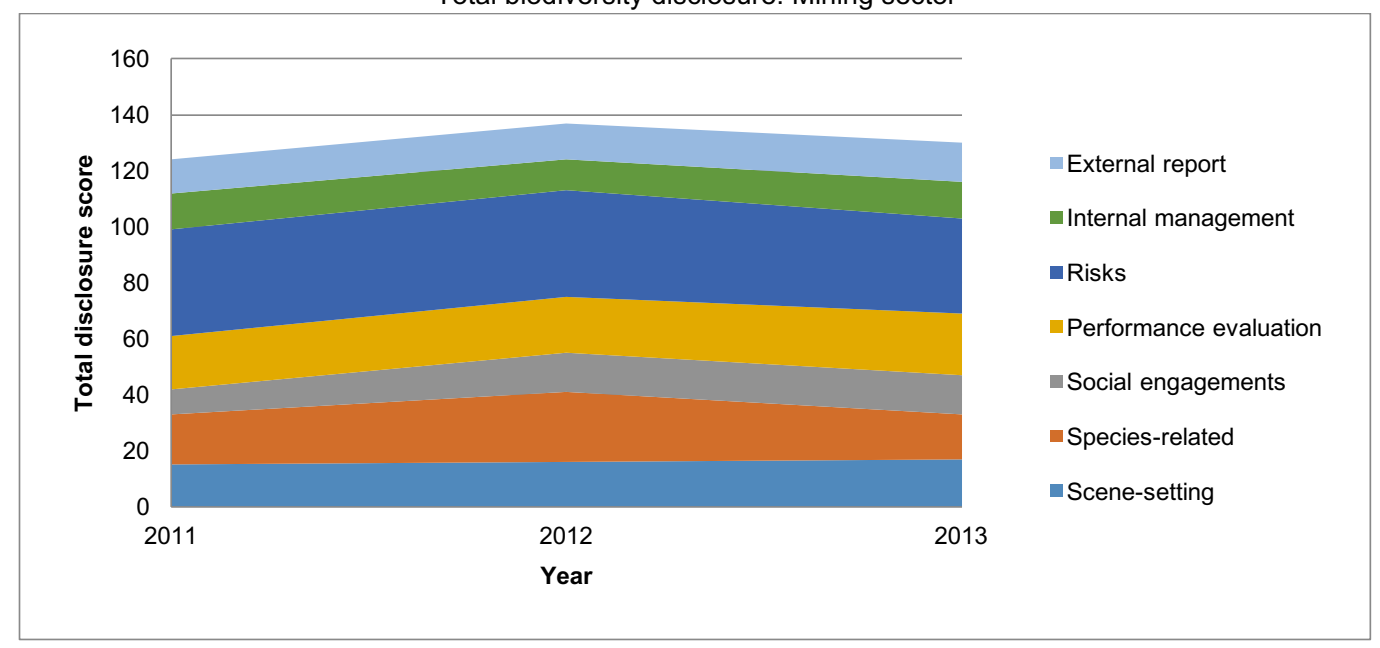

Similar results were found for the food industry. Figure 2 shows a net 5 per cent increase in disclosure from 74 in 2011 to 78 in 2013. Each theme's disclosure score (with the exception of the scene-setting) decreases marginally from 2011 to 2012 (4 per cent) followed by an increase in disclosure from 2012 to 2013 (10 per cent). As with mining companies, risk disclosures are most frequent ( 26 per cent) but disclosure dealing with social engagement accounts for 23 per cent of the total disclosure score. Internal management ( 7 per cent) and performance evaluation (4 per cent) are not dealt with in detail.

Figure 2

Total biodiversity disclosure: Food sector

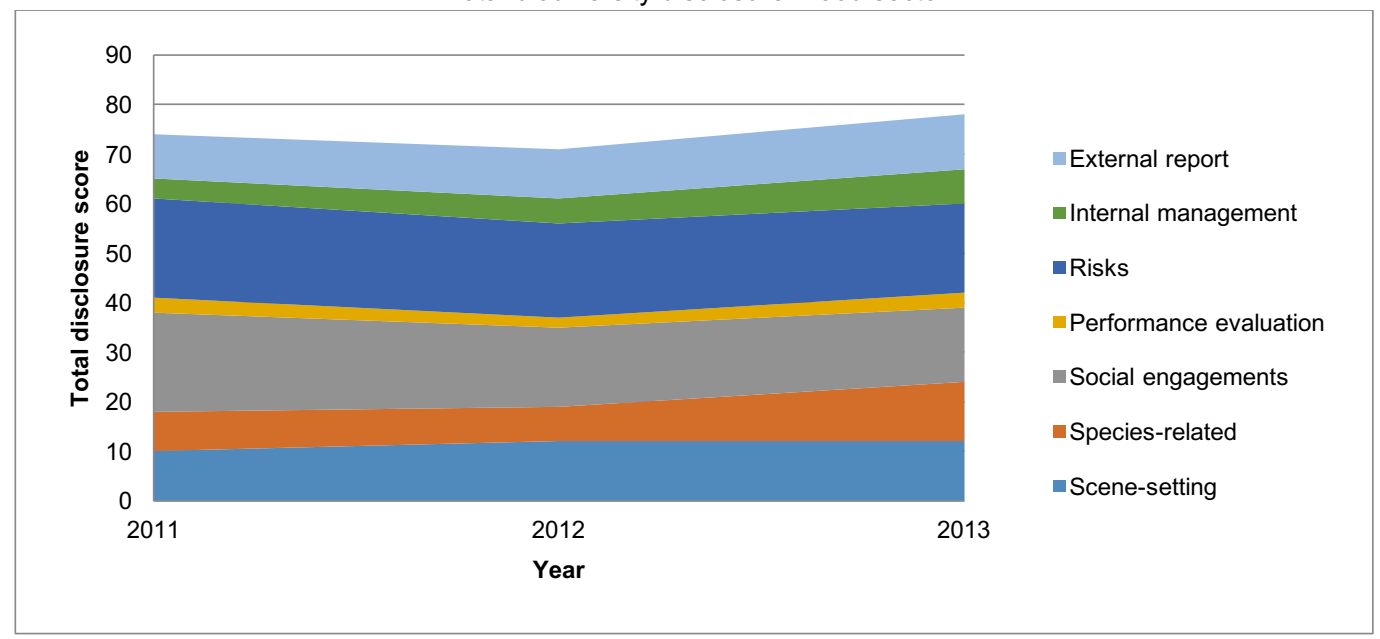

In total, the mining sector included more disclosure on biodiversity issues in the integrated or sustainability reports than the food industry, as indicated by Figure 3. Figure 4 confirms this (as indicated by the relative area covered by the plots) but shows that mining companies concentrate their information, on average, in their sustainability reports (the y-axis). Food producers provide stakeholders with less information but there is more disclosure found in the integrated (the x-axis) than in the sustainability reports (the y-axis). 
Figure 3

Total biodiversity disclosure per sector

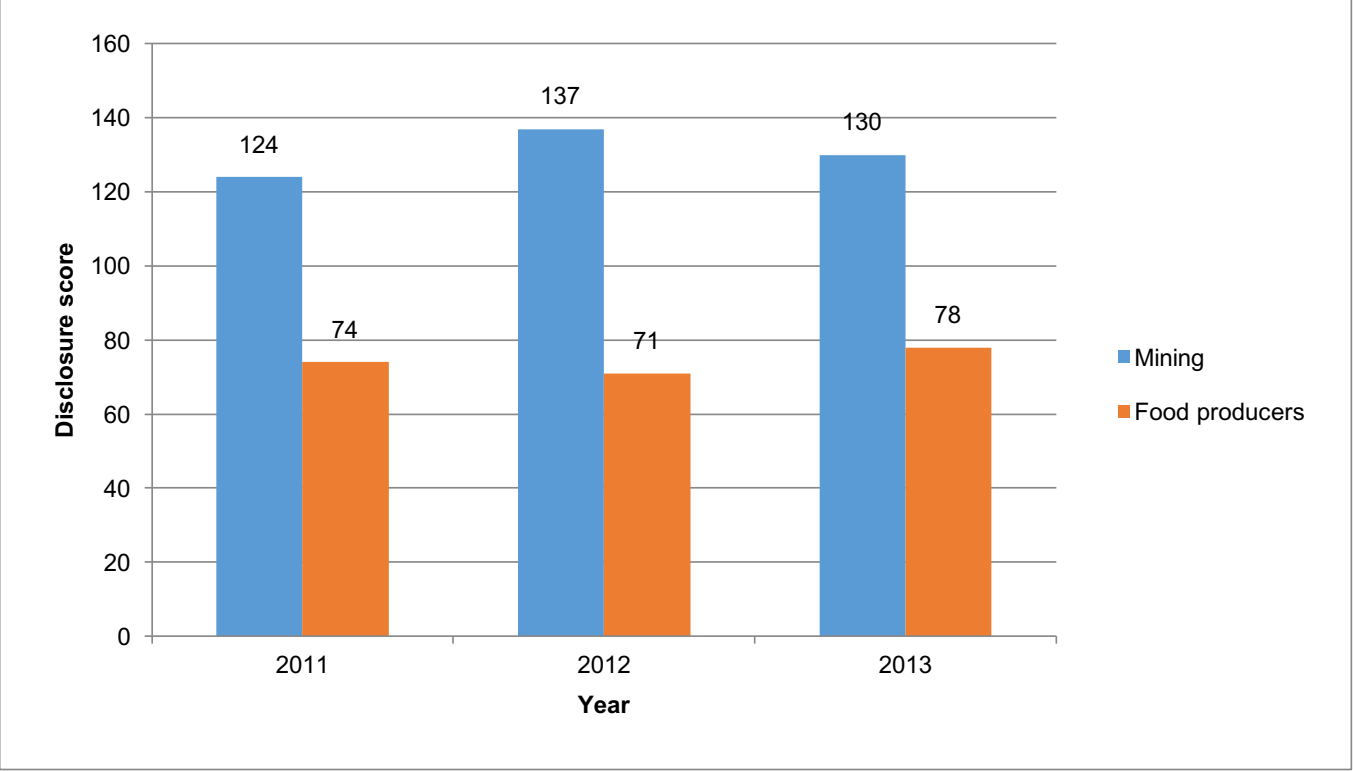

Figure 4

Disclosure score comparison: Mining and food sector ${ }^{7}$

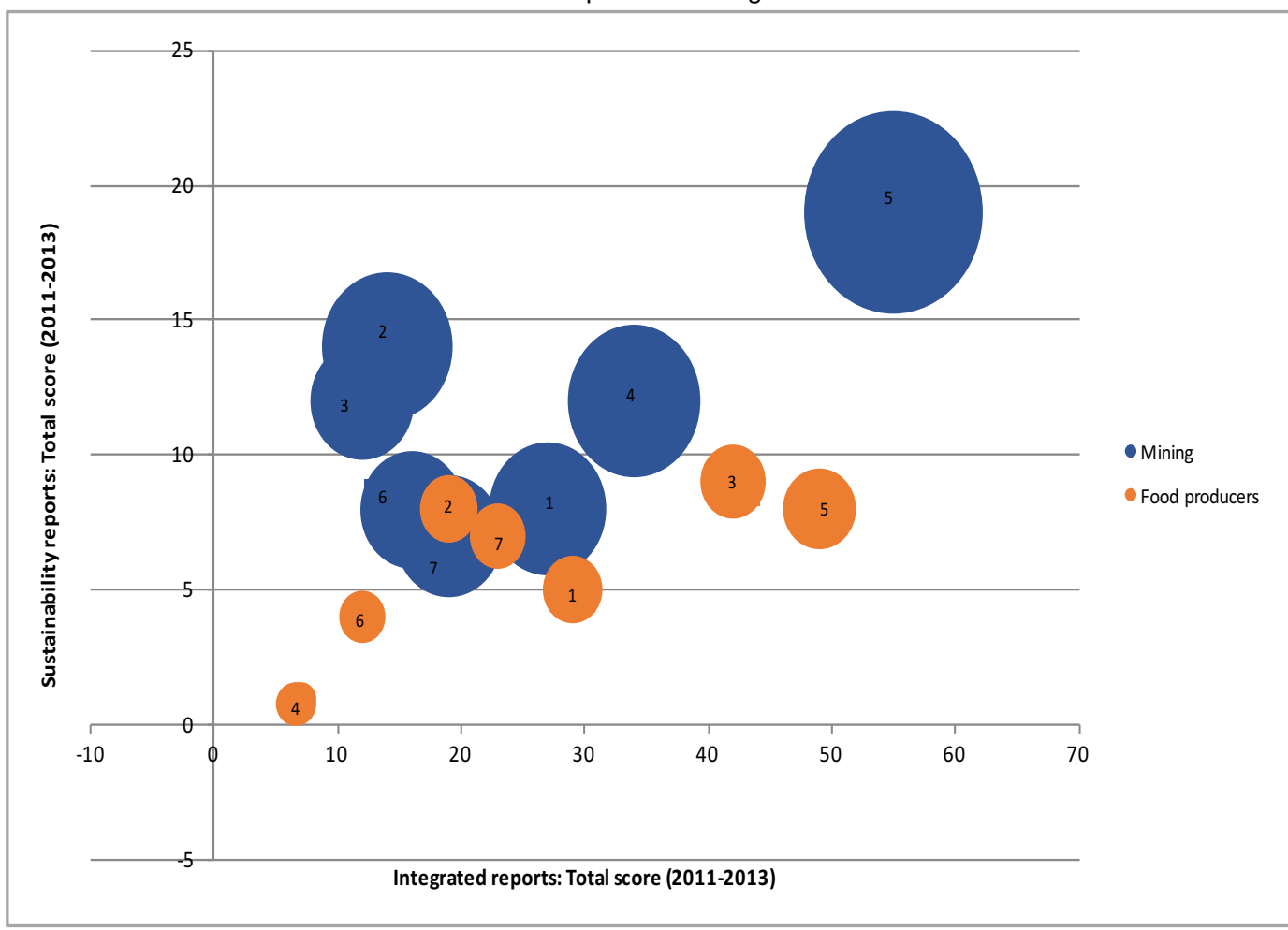




\section{Discussion}

\subsection{The nature of biodiversity disclosure in integrated and sustainability reports}

In South Africa, an integrated report should be the primary means of formally communicating information on the different types of capital under an organisation's control with stakeholders (IOD, 2009; King, 2012; Atkins \& Maroun, 2014). The integrated report should provide a comprehensive assessment of how the respective organisation is managing financial and nonfinancial metrics in order to generate sustainable returns and include the most relevant information for understanding an organisation's business model (IRCSA, 2011). A separate sustainability report should provide only complementary information (King, 2012). In this context, the disclosure score is used as a proxy for the relative level of detail being provided by companies to their stakeholders. The extent to which information is included in the integrated report (rather than the sustainability report) is used as a surrogate for the emphasis on the relative biodiversity issues. The data in Figure 4 can then be represented in Table 3.

The 'emphasis' is recorded as high, if more than half of the disclosure is included in the integrated report. If approximately half of the disclosure is included in the integrated report, the emphasis is reported as moderate. When less than half of the disclosure is in the integrated report, the emphasis is low. 'Detail' refers to the disclosure score per theme. Where a disclosure score is above or below the quotient of the total disclosure score and number of codes, the respective theme is shown as either 'above average' or 'below average' respectively. In addition, those codes which contributed more than 20 per cent of the total score are identified as 'high detail' disclosures. (A 20 per cent cut-off was based on the authors' judgement.) Themes in blue are for the mining industry. Those in red are for the food industry.

Table 3

Product market matrix

\begin{tabular}{|c|c|c|c|c|}
\hline & & \multicolumn{3}{|c|}{ Emphasis } \\
\hline & & High & Medium & Low \\
\hline \multirow[b]{3}{*}{ Detail } & High & $\begin{array}{l}\text { Risk } \\
\text { Social engagement }\end{array}$ & Risk & \\
\hline & Above average & $\begin{array}{l}\text { Performance evaluation } \\
\text { Scene-setting }\end{array}$ & & Species-related \\
\hline & Below average & $\begin{array}{l}\text { Scene-setting } \\
\text { Species-related } \\
\text { Performance evaluation } \\
\text { Internal management } \\
\text { External report }\end{array}$ & External reports & $\begin{array}{l}\text { Social engagements } \\
\text { Internal management }\end{array}$ \\
\hline
\end{tabular}

Both the mining and food sectors placed a high emphasis on risk-related disclosures with this theme code accounting for over 25 per cent of the total disclosure score for each sector. These disclosures were also concentrated in the integrated report initially suggesting that the respective organisations are aware of the relevance of biodiversity-associated risks and the importance of providing information on these risks to stakeholders. Given the high inherent biodiversity risk for these industries (F\&C Asset Management, 2004) at least some risk disclosure is to be expected (Grabsch et al., 2012; Van Liempd \& Busch, 2013). For the mining sector in particular, the content analysis showed that there was some effort to identify specific risks, particular environmental incidents and the materiality of the related biodiversity impact.

In total, however, the disclosures are very limited. On average, biodiversity-related information is only reported 60 or 59 times in the integrated reports of companies in the mining and food 
industry respectively, over the 3 years. Added to this is the fact that, where information is being disclosed in the integrated report, insufficient detail is provided to ensure adequate accountability. For example, figures 1 and 2 show that disclosures dealing with internal management make one of the lowest contributions to the total disclosure score of the mining ( 9 per cent) and food ( 7 per cent) industry. In addition, Table 3 and Figure 4 show the little information which is provided by the former sector is often located in the sustainability reports, suggesting that mining companies are, on average, placing less emphasis on this type of disclosure.

Companies in the food sector may be placing most of their internal management information in integrated reports (Table 3 ) but specific biodiversity action plans are not apparent and there is no indication of a dedicated biodiversity officer for ensuring an integrated approach for managing biodiversity risk (see also Grabsch et al., 2012; Van Liempd \& Busch, 2013). Where references were made to specific plans for managing biodiversity, these were normally accompanied by an explanation of the relevant legislation or code of practice which required the initiative. This suggests a compliance motive, rather than a genuine interest in prudential biodiversity management. The same was the case in the mining sector.

Adding to this view is the nature of disclosure dealing with reporting guidelines. The information being included in the integrated or sustainability reports in both sectors addressed whether or not and the extent to which the relevant reporting frameworks were being applied. There was no indication that these were being used to create new lines of performance measurement and evaluation. Similarly, target performance and cost disclosure was generic. Some companies made reference to issues such as climate change, pollution prevention, emission monitoring or biodiversity loss. This, however, constituted only 16 per cent of biodiversity disclosures by mining companies and a mere 4 per cent of the total disclosure score of the food sector. Contrary to the recommendations of the IIRC (2013), there were only isolated instances where key performance indicators dealt specifically with biodiversity loss and were clearly linked to the management of the different types of capital (including environmental and social variants) identified by the IIRC (2013).

Perhaps the clearest indicator of an inadequate approach to biodiversity management and integrated reporting is the fact that none of the companies under review provided a clear definition of 'biodiversity'. This went hand-in-hand with below average disclosure of mission statements as per the plotting and size of the scene-setting code in Figure 4. It is, therefore, unsurprising that mining companies provide little on the specific species affected by their operations and deemphasise this type of disclosure by limiting it mainly to the sustainability reports (Table 3 ). Similarly, although the food industry includes scene-setting and species-information mainly in the integrated reports (see Table 3), these theme codes included only 34 and 27 references in both types of reports over the three years under review, implying less than one reference (on average) per company over the period covered by the research.

\subsection{Possible explanations for limited biodiversity reporting}

It is difficult to identify a specific reason for limited biodiversity reporting based only on a review of the disclosures found in integrated and sustainability reports. A number of inferences can, however, be drawn.

\section{On the relevance of legitimacy}

As discussed in Section 3.2, added public attention because of environmental issues goes hand-inhand with changes in the nature and extent of environmental reporting as organisations attempt to manage actual or perceived threats to their credibility by altering the information communicated to stakeholders (O’Donovan, 2002; Patten, 2002; Brennan \& Merkl-Davies, 2014). The results presented in Section 4 are, however, at odds with these reporting patterns.

The risks posed by climate change, uncontrolled population growth and habitat destruction are well documented (Jones \& Solomon, 2013), increasingly have been the subject of public debate 
(for example, see IPCC, 2013) and have been specifically referred to by codes of best reporting practice and governance (IOD, 2009; KPMG, 2012; GRI, 2014). Nevertheless, figures 1 and 2 show marginal changes in biodiversity-specific information being included in the integrated and sustainability reports from 2011 to 2013.

Limited understanding about biodiversity and absence of detailed guidelines for reporting on biodiversity-related issues provide one explanation for this (Grabsch et al., 2012; Van Liempd \& Busch, 2013). A more critical view is that large companies in the South African mining and food industry do not regard biodiversity management as a significant threat to their legitimacy with the result that the ongoing debate on issues such as habitat loss and mass extinction do little to increase the emphasis placed on these matters in integrated reports.

This interpretation provides a reasonable explanation for why the mining industry has, for example, decreased biodiversity disclosure in its integrated reports from 64 to 50 mentions from 2011 to 2013. The sector is cognisant of the fact that its general environmental performance is regulated and subject to public scrutiny (Department of Environmental Affairs et al., 2013). For this reason, the industry has gone to great lengths to ensure compliance with the GRI's guidelines on environmental reporting (Hindley \& Buys, 2012); to increase the extent of information on generally expected environmental issues included in integrated reports (Carels et al., 2013); and to align the nature and extent of its environmental reporting with international benchmarks (De Villiers et al., 2014). If, however, the biodiversity debate has not focused the public's attention on, for example, the importance of biodiversity action plans, impact assessments on specific species and incident reviews, a balance should be struck.

On the one hand, failing to report can be interpreted as an indicator that the industry is either completely unaware or uninterested, giving rise to criticism. In this context, all of the companies under review included at least some information on biodiversity management in their corporate reports. On the other hand, excessive disclosure enables accountability and can have the unintended effect of attracting adverse attention from stakeholders who, paradoxically, may never have been aware of the importance of biodiversity management (cf De Villiers \& Van Staden, 2006). In this light, Section 5.1 has argued that most of the information on biodiversity is generic. Contemporaneously, case-specific information (such as internal management plans) are deemphasised by mining companies by including the disclosure in the sustainability report rather than the integrated report.

When it comes to the food sector, managing organisational legitimacy remains relevant although a slightly different strategy is applied. As with mining companies, the sector must be cautious about over-reporting in the absence of an explicit threat to their existing credibility. Once again, this explains the low disclosure scores and the very general information being included in the corporate reports per Section 5.1. Unlike the mining sector, however, outputs are less standardised, prices are not determined solely by the resources market and the sector is more focused on the general consumer. Consequently, biodiversity management can be used as part of a strategy to differentiate products, penetrate or defend market share and command a price premium ${ }^{8}$ (cf Botten, 2009). As such, companies in the food sector often include case studies dealing with specific species and examples of stakeholder engagement (see Table 3) designed to present themselves in a positive light (see also Deegan et al., 2002; Solomon et al., 2013). Most of this information is presented in integrated reports (see Table 3 and Figure 4) to ensure prominence. Contemporaneously, there are few references to biodiversity-related shortcomings; and none of the companies included in the sample attempts to quantify the cost of its operations on South Africa's biodiversity.

\section{The importance of stakeholders}

The manner in which companies in the food and mining industry are balancing the expectation, for at least, some information on biodiversity with the need to avoid unnecessary public scrutiny, also sheds some light on stakeholder awareness and activism in South Africa. There are few papers that 
deal with this issue. A notable exception is a fairly recent (albeit preliminary) study by Rensburg and Botha (2014) which finds low levels of financial literacy among South African investors and a lack of awareness of the importance of key financial and non-financial metrics. A similar situation is found by Atkins and Maroun $(2014 ; 2015)$ who analyse institutional investors' views on the integrated reports being prepared by South African corporates. Poor financial skills and a limited awareness of relevant corporate governance principles were particularly evident when it came to the trustees of some of the country's pension funds.

It is reasonable to argue that this general lack of understanding by key stakeholders contributes to limited stakeholder activism in South Africa (Atkins \& Maroun, 2014; 2015) and, in turn, undermines demands for high quality corporate reporting which deals adequately with the risk of biodiversity loss. The relevance of finance and economic paradigms cannot, however, be overlooked.

As argued by Tregidga et al. (2014) corporate disclosure has developed in the context of the pressures of the capital market system with the result that 'sustainability' must be contextualised and interpreted in terms of economic performance. As discussed in Section 5.1, the absence of clear reporting guidelines poses a challenge for organisations grappling with the meaning of 'biodiversity' and precisely what information to include in their corporate reports. Compounding this problem is the fact that a framework for drawing an interconnection between biodiversity, business strategy and operating costs is non-existent (Jones \& Solomon, 2013). Difficulties in quantifying and disclosing the costs and benefits of biodiversity management provide an additional explanation for the limited extent to which the sample of companies under review are reporting on issues such as biodiversity action plans and performance against predetermined indicators (as shown in figures 1 and 2).

More critical is the possibility that, even when stakeholders are fully aware of the objectives of integrated reporting and the importance of biodiversity issues, short-term economic focus continues to be the dominant factor (cf Gray, 2013), especially when it comes to the country's institutional investors (Atkins \& Maroun, 2014). There is some evidence to suggest that nonfinancial reporting can be value-relevant but results are generally mixed (De Klerk \& De Villiers, 2012). Furthermore, there is no guarantee that the emergence of integrated reporting has resulted in a paradigm shift in the approach to investment appraisal being followed by finance houses (Atkins \& Maroun, 2014). Consequently, biodiversity reporting - as with other non-financial measures - may continue to be seen as a complementary process driven by social expectations, rather than being internalised as an integral part of the assessment of an organisation's ability to create and sustain value in the long-run. To paraphrase Gray $(2012$, p. 4), in the evaluation of the reasons for the slow development of sustainability (including biodiversity) reporting, there is a 'conspicuous absence of any notion that it is investors and financial markets that may be the key components in financial instability, social injustice and environmental un-sustainability'.

\section{Providing an account}

In functional terms, accounting is 'infused by a rhetoric of economic and managerial rationality' (Hopwood, 1987:210) which can easily obscure the potential of accounting systems to promote new lines of economic and social visibility and engender change (Burchell, Clubb, Hopwood, Hughes \& Nahapiet, 1980; Miller \& O’Leary, 1987; Cowton \& Dopson, 2002; Quattrone, 2004). This is especially relevant in the context of non-financial reporting where there is evidence of how sound environmental, social and governance practices are becoming a social imperative (De Villiers \& van Staden, 2006; Brennan \& Merkl-Davies, 2014; Tregidga et al., 2014) and at least some indication of these metrics being taken into account by the investor community (De Klerk \& De Villiers, 2012; Atkins \& Maroun, 2014; 2015).

To this end, for the organisation prepared to take a long-term position on integrated reporting, there is value in investing in systems and processes which can provide an assessment (even if this is only a broad estimate) of the total economic cost and benefit of operations (Nunes \& Van den 
Bergh, 2001; Short et al., 2013). Unfortunately, the rate at which organisations' integrated reports are evolving to provide a comprehensive account of the management of the different capitals under the reporting entity's control (including its environmental and social capital) has been slow (King, 2012; Solomon \& Maroun, 2012; Gray, 2013).

As touched on in Section 5.2, international financial reporting standards and the reporting recommendations of the IIRC and GRI may have a role to play in this regard. Presently, there is no generally accepted basis for defining, identifying and measuring changes in the biodiversity mass attributable to the reporting entity. As a result, it is difficult to quantify and provide a truly integrated assessment of an organisation's environmental impact. In a capital-centric reporting environment, where sustainability is understood in financial terms (Tregidga et al., 2014), the effect of the loss on biodiversity on the net assets of the reporting entity is left unreported, leaving companies with little incentive to alter the status quo.

At this point, it should be noted that the authors are not advocating for an alternative to capitalism. Instead, we acknowledge the relevance of finance and economics for decision-making and, therefore, encourage the refinement of accounting to promote change within existing capital systems. In this context, what is needed is a general framework for accounting for changes in environmental capital, including biodiversity mass. Rather than absolute precision, the aim is to provide an initial estimate of the costs of biodiversity loss in order to promote the development of a new field of 'visibility' which can lead to enhanced accountability and promote change to existing business practice. There has already been some work in this regard.

Cuckston (2013), for example, uses the case of forest conservation in Kenya to demonstrate how the construction of a 'calculable good' which can be traded on an active market can be used to provide a surrogate financial measure of the value of a given biome. Similarly, Freeman and Groom (2013) examine the appropriateness of mainstream approaches for discounting environmental provisions, arguing that conceptually-backed adjustments to the discount rate provide a superior assessment of the true costs of industrial activity. This is true even if this incorporates a higher degree of subjectivity into the financial results. The recently released IFRS 13 (IASB, 2011) offers additional opportunities. It may not be possible, for example, for a company to value a stream from which it draws water or a natural forest from which it sources timber. If the principle of market-equivalent replacement cost (which is frequently used in traditional financial valuations) is applied by analogy (IASB, 2003; IASB, 2011), the reporting entity can use the cost of obtaining an alternate supply of the equivalent or substitute goods to provide stakeholders with at least some indication of the value of the respective biodiversity system.

These are only initial recommendations from the existing literature. Numerous practical and theoretical difficulties are likely to be encountered (Cuckston, 2013) which will need to be the subject of detailed research. Nevertheless, as explained by Jones and Solomon (2013:710), monetisation of biodiversity loss - even if this is rudimentary - at least 'has the potential to alter radically humankind's economic relationships with the myriad of species that comprise earth's global ecosystem' and to encourage change.

\section{Conclusion}

This research examines the extent of biodiversity reporting by a sample of South African companies in the mining and food industry. The study is not without limitations. It is based on a relatively small sample and a subjective coding process to collect data and make inferences about the nature and extent of biodiversity reporting. Nevertheless, this preliminary study provides one of the first accounts of biodiversity disclosures in South Africa. The findings show that, despite the chosen industries being identified as having high environmental impacts, biodiversity disclosures are very limited. This is especially interesting, given the on-going public debate on habitat loss and mass extinction and mounting scientific evidence of a looming environmental catastrophe. These results are consistent with the most recent research on biodiversity reporting which is based in the 
U.K, Germany and Denmark (Grabsch et al., 2012; Van Liempd \& Busch, 2013) but the results are inconsistent with the fact that South Africa boasts one of the most developed codes on corporate governance and has been advancing the preparation of integrated reports since 2010 .

A possible explanation is that 'biodiversity' has not been clearly defined by the reporting frameworks being used by South African companies to prepare their integrated and sustainability reports (cf Grabsch et al., 2012; Van Liempd \& Busch, 2013). Furthermore, King-III (IOD, 2009), the IRCSA (2011) and IIRC (2013) focus on principles and do not provide specific guidance on the nature and extent of biodiversity-related information which should be included in corporate reports.

It is, however, not very comforting if large listed companies are unable to appreciate the context in which they are doing business and without reporting prescriptions do not report on the environmental issues which should be communicated to their stakeholders. This raises questions about the extent to which they are committed to identifying and managing long-term environmental concerns and communicating this transparently to users of the integrated and sustainability reports. Contemporaneously, one needs to ask what is being done by large institutional investors and environmental activist in South Africa. It does not require a complex scientific analysis to conclude that mass extinction, climate change and habitat destruction are significant socio-economic challenges and important long-term business risks. The results of this study, however, provide little evidence of meaningful stakeholder engagement, begging the question: Why are institutional investors, regulatory bodies and NGOs not engaging with companies and calling them to account for poor biodiversity reporting?

In a capital-centric market environment, so-called 'soft-issues' can easily be overlooked, especially if the information is not being integrated with key performance measures, corporate strategies and financial results. A long-term solution for changing this mind-set is beyond the scope of this research". What is, however, a possible way forward is attempts to 'monetise' the biodiversity mass on which organisations are dependent in order to contextualise this environmental indicator in terms of existing capital paradigms. There are few studies which have in detail dealt with the practicalities of this approach but some examples are available, including the use of adjusted discount rates to take environmental risk into account and the concept of equivalent replacement costs to provide an estimate of biodiversity value.

Each of these approaches (and other methods) could be investigated more thoroughly by future researchers. This can go hand-in-hand with more detailed research - based on large sample sizes to document the extent of biodiversity reporting, its value relevance and the nature of information which stakeholders expect to be reported. Detailed interviews with different preparers and stakeholders are also necessary to understand the best means for communicating information on changes in biodiversity mass and the inherent challenges.

The initial accounting for changes in environmental capital (including biodiversity) will, no doubt, be very basic and, arguably, too subjective to justify inclusion in formal statements of profit or loss or financial position. This will, however, be an important start in providing a basis for including biodiversity indicators in mainstream measures of performance and ensure that biodiversity reporting resonates with dominant economic and finance paradigms which continue to drive corporate practice and decision-making. The way forward is not entirely clear but what is well-known is that:

'Through its intertwining with the discursive notions of accountability and responsibility, accounting can play a role in the reconstitution of organisational agents, enabling different configurations of organisational arrangements to exist' (Hopwood, 1987:229).

\section{Endnotes}

Acronyms commonly used in this paper include: Global Reporting Initiative (GRI); Institute of Directors in Southern Africa (IOD); Intergovernmental Panel on Climate Change (IGPCC); International Integrated Reporting Council (IIRC); South African National Biodiversity Institute (SANBI) 
1 Global biodiversity: Status of the earth's living resources' by the World Conservation Monitoring Centre in 1992.

2 Approximately USD7 billion

3 Social and stakeholder engagement are separately identified by Grabsch et al. (2012). For the purpose of this research, these themes are merged as the descriptions are similar and because, in South Africa, integrated reporting and local codes on corporate governance specifically include social engagement as part of a broader stakeholder-centric reporting model.

4 The size of the company is considered to affect significantly the extent of disclosures made: as the accumulation and distribution of information is costly, larger companies are deemed to have the resources to absorb such costs (Buzby, 1975; Cooke, 1992)

5 Note that social engagement and stakeholder engagement are treated as a single theme due to their similarity.

6 The numbers in each cell correspond with the disclosure theme/code in Table 2 and Section 4.2.

7 Further analysis of precisely how biodiversity management or more general environmental, social and governance disclosures are used strategically by organisations is not specifically within the scope of this research.

8 Some may argue that this will only be possible after environmental calamity forces a change in business ethos.

9 Pick and Pay Holdings Limited and Pick and Pay Stores Limited are both listed on the JSE and originally formed part of the sample. Pick and Pay Holdings Limited was, however, excluded from the sample as only one set of reports is prepared for both Pick and Pay Stores Limited and Pick and Pay Holding Limited

10 Grabsch et al. (2012) refer to disclosures regarding environmental liabilities per the Directive of the European Union. This is excluded from the checklist as it is considered irrelevant in the South African context.

\section{References}

ATKINS, J. \& MAROUN, W. 2014. South African institutional investors' perceptions of integrated reporting. In: ACCA (ed.) The association of chartered certified accountants: London.

ATKINS, J. \& MAROUN, W. 2015. Integrated reporting in South Africa in 2012: Perspectives from South African institutional investors. Meditari Accountancy Research, 23(2):197-221.

BOIRAL, O. 2016. Accounting for the unaccountable: Biodiversity reporting and impression management. Journal of Business Ethics, 135(4):751-768

BOTTEN, N. 2009. Management accounting business strategy. (2009 ed.) Oxford, United Kingdom, CIMA Publishing.

BRENNAN, N. \& MERKL-DAVIES, D. 2014. Rhetoric and argument in social and environmental reporting: The dirty laundry case. Accounting, Auditing \& Accountability Journal, 27(4):602-633.

BURCHELL, S., CLUBB, C., HOPWOOD, A., HUGHES, J. \& NAHAPIET, J. 1980. The roles of accounting in organizations and society. Accounting, Organizations and Society, 5(1):5-27.

BUZBY, S.L. 1975. Company size, listed versus unlisted stocks, and the extent of financial disclosure. Journal of Accounting Research, 13(1):16-37, Spring 1975.

CARELS, C., MAROUN, W. \& PADIA, N. 2013. Integrated reporting in the South African mining sector. Corporate Ownership and Control, 11(1):991-1005.

CHO, C.H., LAINE, M., ROBERTS, R.W. \& RODRIGUE, M. 2015. Organized hypocrisy, organizational façades, and sustainability reporting. Accounting, Organizations and SocietyI, 40(0):78-94.

COOKE, T.E. 1992. The impact of size, stock market listing and industry type on disclosure in the annual reports of Japanese listed corporations. Accounting and Business ResearchI, 22(87):229-237.

COWTON, C.J. \& DOPSON, S. 2002. Foucault's prison? Management control in an automotive distributor. Management Accounting Research, 13(2):191-213.

CUCKSTON, T. 2013. Bringing tropical forest biodiversity conservation into financial accounting calculation. Accounting, Auditing \& Accountability JournalI, 26(5):688-714.

DE KLERK, M. \& DE VILLIERS, C. 2012. The value relevance of corporate responsibility reporting: South African evidence. Meditari Accountancy Research, 20(1):21-38.

DE VILLIERS, C. \& ALEXANDER, D. 2014. The institutionalisation of corporate social responsibility reporting. The British Accounting Review, 46 (2):198-212.

DE VILLIERS, C., LOW, M. \& SAMKIN, G. 2014. The institutionalisation of mining company sustainability disclosures. Journal of Cleaner Production, 84:51-58.

DE VILLIERS, C. \& VAN STADEN, C.J. 2006. Can less environmental disclosure have a legitimising effect? Evidence from Africa. Accounting, Organizations and Society, 31(8):763-781.

DE VILLIERS, C.J. \& BARNARD, P. 2000. Environmental reporting in South Africa from 1994 to 1999: A research note. Meditari Accountancy Research, 8(1):15-23. 
DEEGAN, C., RANKIN, M. \& TOBIN, J. 2002. An examination of the corporate social and environmental disclosures of BHP from 1983-1997. Accounting, Auditing \& Accountability Journal, 15(3):312-343. DEPARTMENT OF ENVIRONMENTAL AFFAIRS AND TOURISM (DEAT). 1998. Convention on biological diversity: South African national report to the Fourth Conference of the Parties Department. In: TOURISM, D.O.E.A.A. (ed.) South Africa.

DEPARTMENT OF ENVIRONMENTAL AFFAIRS AND TOURISM (DEAT). 2009. South Africa's fourth national report to the convention on biological diversity. Republic of South Africa.

DEPARTMENT OF ENVIRONMENTAL AFFAIRS, DEPARTMENT OF MINERALS AND

RESOURCES. Chamber of Mines, South African mining and biodiversity forum \& South African National Biodiversity Institute 2013. Mining and Biodiversity Guideline: Mainstreaming biodiversity into the mining sector. Pretoria.

ENDANGERED WILDLIFE TRUST. 2015. Biodiversity and mining. Mining impacts.

F\&C ASSET MANAGEMENT. 2004. Is biodiversity a material risk for companies? An assessment of the expposure of FTSE sectors to biodiversity risk. London: F\&C Asset Management.

FREEMAN, M.C \& GROOM, B. 2013. Biodiversity valuation and the discount rate problem. Accounting, Auditing \& Accountability Journal, 26(5):715-745.

GLOBAL REPORTING INITIATIVE. 2007. Biodiversity: A GRI reportingresource.

http:/www.globalreporting.org/resourcelibrary/Biodiversity-A-GRI-Resource-Document.pdf [accessed August 2014].

GLOBAL REPORTING INITAITIVE (GRI). 2014. G4 Sustainability reporting guidelines.

https://www.globalreporting.org/reporting/g4/Pages/default.aspx [accessed February 2015].

GRABSCH, C., JONES, M.J. \& SOLOMON, J.F. 2012. Accounting for biodiversity in crisis: A European perspective. Working Paper, Kings College London. London.

GRAY, R., KOUHY, R. \& LAVERS, S. 1995. Corporate social and environmental reporting. Accounting, Auditing \& Accountability Journal, 8(2):47-77.

GRAY, R. 2006. Social, environmental and sustainability reporting and organisational value creation? Accounting, Auditing \& Accountability Journal, 19(6):793-819.

GRAY, R. 2010. Is accounting for sustainability actually accounting for sustainability... and how would we know? An exploration of narratives of organisations and the planet. Accounting, Organizations and Society, 35(1):47-62.

GRAY, R. 2012. Integrated reporting: Integrated with what and for whom? https://risweb.standrews.ac.uk/portal/en/researchoutput/integrated-reporting-integrated-with-what-and-for-whom(f979768951b2-4bb0-b158-e3a6ab0904ca).html [accessed July 2014].

GRAY, R. 2013. Back to basics: What do we mean by environmental (and social) accounting and what is it for?-A reaction to Thornton. Critical Perspectives on Accounting, 24(6):459-468.

HIGGINS, C. \& WALKER, R. 2012. Ethos, logos, pathos: Strategies of persuasion in social/environmental reports. Accounting Forum, 36(3):194-208.

HINDLEY, T. \& BUYS, P. 2012. Integrated reporting compliance with the global reporting initiative framework: An analysis of the South African mining industry. International Business \& Economics Research Journal, 11(11):1249-1260.

HOPWOOD, A.G. 1987. The archaeology of accounting systems. Accounting, Organizations and Society, 12(3):207-234.

INTERNATIONAL ACCOUNTING STANDARDS BOARD (IASB). 2003. International accounting standard 8: Accounting policies, changes in accounting estimates and errors. http://eifrs.ifrs.org/ eifrs/files/238/bv2012_ias08_part\%20a_149.pdf [accessed January 2013].

INTERNATIONAL ACCOUNTING STANDARDS BOARD (IASB). 2011. International financial reporting standard 13: Fair value measurement. http://eifrs.ifrs.org/eifrs/files/238/bv2012_ifrs13_part\% 20a_135.pdf [accessed January 2013].

INTERNATIONAL INTEGRATED REPORTING COUNCIL (IIRC). 2013. The international framework: Integrated reporting. http://www.theiirc.org/wp-content/uploads/2013/12/13-12-08-THE-

INTERNATIONAL-IR-FRAMEWORK-2-1.pdf [accessed October 2013]. 
INTERGOVERNMENTAL PANEL ON CLIMATE CHANGE. 2013. Climate change 2013: The physical science basis. http://www.ipcc.ch/report/ar5/wg1/ [accessed June 2015].

INTERNATIONAL COUNCIL ON MINING AND METALS 2006. Good practice guidance for mining and biodiversity. London: International Council on Mining and Metals.

INSTITUTE OF DIRECTORS IN SOUTHERN AFRICA (IOD) 2009. The King code of governance for South Africa (2009) and King report on governance for South Africa (2009) (King-III), Lexis Nexus South Africa, Johannesburg, South Africa.

INTEGRATED REPORTING COMMITTEE OF SOUTH AFRICA (IRCSA). 2011. Framework for integrated reporting and the integrated report. www.sustainabilitysa.org [accessed June 2012].

JOHANNESBURG STOCK EXCHANGE (JSE). 2013. JSE listing requirments. https://www.jse.co.za/ content/JSEEducationItems/Service\%20Issue\%2017.pdf [accessed February 2015].

JONES, M.J. 1996. Accounting for biodiversity: A pilot study. British Accounting Review, 28:281-303.

JONES, M.J. 2010. Accounting for the environment: Towards a theoretical perspective for environmental accounting and reporting. Accounting Forum, 34(2):123-138.

JONES, M.J. \& SOLOMON, J.F. 2013. Problematising accounting for biodiversity. Accounting, Auditing \& Accountability Journal, 26(5):668-687.

KAENNEL, M. 1998. Biodiversity: A diversity in definition. Assessment of biodiversity for improved forest planning. Springer.

KING, M. 2012. Comments on: Integrated reporting and the integrated report. Public Lecture. International Corporate Governance Conference, Johannesburg, South Africa. 23 October.

KPMG. 2012. Carrots and sticks - Promoting transparency and sustianability: An update on trends in voluntary and mandatory approaches to sustainability reporting. https://www.globalreporting.

org/resourcelibrary/Carrots-And-Sticks-Promoting-Transparency-And-Sustainbability.pdf [accessed June 2013].

LEEDY, P.D. \& ORMROD, J.E. 2013. Practical research planning and design, New York, Pearson Education Inc.

MAROUN, W., COLDWELL, D. \& SEGAL, M. 2014. SOX and the transition from apartheid to democracy: South African auditing developments through the lens of modernity theory. International Journal of Auditing, 18(3):206-212.

MERKL-DAVIES, D., BRENNAN, N. \& VOURVACHIS, P. 2011. Text analysis methodologies in corporate narrative reporting research. In: 23rd CSEAR International Colloquium. St Andrews, United Kingdom, 2011.

MEYER, J.W. \& ROWAN, B. 1977. Institutionalized organizations: Formal structure as myth and ceremony. American Journal of Sociology, 83(2):340-363

MILLENNIUM ECOSYSTEM ASSESSMENT 2005. Chapter 4: Biodiversity in Ecosystems and human well-being: Current state and trends. Washington, DC.

MILLER, P. \& O'LEARY, T. 1987. Accounting and the construction of the governable person. Accounting, Organizations and Society, 12(3):235-265.

NUNES, P.A.L.D. \& VAN DEN BERGH, J.C.J.M. 2001. Economic valuation of biodiversity: Sense or nonsense? Ecological Economics, 39(2):203-222

O'DONOVAN, G. 2002. Environmental disclosures in the annual report. Accounting, Auditing \& Accountability Journal, 15(3):344-371.

O'DWYER, B. 2002. Managerial perceptions of corporate social disclosure: An Irish story. Accounting, Auditing \& Accountability Journal, 15(3):406-436.

PATTEN, D.M. 1992. Intra-industry environmental disclosures in response to the Alaskan oil spill: A note on legitimacy theory. Accounting, Organizations and Society, 17(5):471-475.

PATTEN, D.M. 2002. The relation between environmental performance and environmental disclosure: A research note. Accounting, Organizations and Society, 27(8):763-773.

QUATTRONE, P. 2004. Accounting for God: Accounting and accountability practices in the Society of Jesus (Italy, XVI-XVII centuries). Accounting, Organizations and Society, 29(7):647-683.

RAEMAEKERS, K., MAROUN, W. \& PADIA, N. 2015. Risk disclosures by South African listed companies post-King III. South African Journal of Accounting Research, 1-20. 
RENSBURG, R. \& BOTHA, E. 2014. Is integrated reporting the silver bullet of financial communication? A stakeholder perspective from South Africa. Public Relations Review, 40(2):144-152.

RIMMEL, G. \& JONÄLL, K. 2013. Biodiversity reporting in Sweden: Corporate disclosure and preparers' views. Accounting, Auditing \& Accountability Journal, 26(5):746-778.

SAMKIN, G., SCHNEIDER, A. \& TAPPIN, D. 2014. Developing a reporting and evaluation framework for biodiversity. Accounting, Auditing \& Accountability Journal, 27(3):527-562.

SCOTCHER, J.S.B. 2009. The green choice living farms Reference 2009/2010 version. World Wide Fund for Nature and Conservation International.

SHORT, M.D., PETERS, G.M., PEIRSON, W.L. \& ASHBOLT, N.J. 2013. Marine nitrous oxide emissions: An unknown liability for the international water sector. Environmental Science \& Policy, 33:209-221.

SIZEMORE, G.C. 2015. Accounting for biodiversity in the dairy industry. Journal of Environmental Management, 155:145-153

SOLOMON, J. 2010. Corporate governance and accountability. ( $3^{\text {rd }}$ ed.) West Susex, United Kingdom, John Wiley and Sons Ltd.

SOLOMON, J. \& MAROUN, W. 2012. Integrated reporting: The new face of social, ethical and environmental reporting in South Africa? In: ACCA (ed.) The Association of Chartered Certified Accountants: London.

SOLOMON, J.F., SOLOMON, A., JOSEPH, N.L. \& NORTON, S.D. 2013. Impression management, myth creation and fabrication in private social and environmental reporting: Insights from Erving Goffman. Accounting, Organizations and Society, 38(3):195-213.

SOUTH AFRICAN INSTITUTE OF CHARTERED ACCOUNTANTS. 2013. King- King report on corporate governance https://www.saica.co.za/Technical/LegalandGovernance/King/tabid/ 2938/language/en-ZA/Default.aspx [accessed August 2014].

SOUTH AFRICAN NATIONAL BIODIVERSITY INSTITUTE (SANBI). 2015. Sustainable Agriculture South Africa. http://biodiversityadvisor.sanbi.org/industry-and-conservation/conservation-andagriculture/sustainable-agriculture-2/ [accessed March 2015].

SOUTH AFRICAN NATIONAL BIODIVERSITY INSTITUTE 2010. Biodiversity information policy document- Policy Series: Principle and Guidelines. South Africa.

SOUTH AFRICAN NATIONAL BIODIVERSITY INSTITUTE. 2014. SANBI Biodiversity for life. http://www.sanbi.org/ [accessed August 2014].

SOUTH AFRICAN NATIONAL BIODIVERSITY INSTITUTE. 2015. Biodiversity and Agriculture $\mathrm{http}$ ///biodiversityadvisor.sanbi.org/industry-and-conservation/conservation-and-agriculture/ [accessed January 2015].

SUCHMAN, M.C. 1995. Managing legitimacy: Strategic and institutional approaches. The Academy of Management Review, 20(3):571-610.

TREGIDGA, H., MILNE, M. \& KEARINS, K. 2014. (Re)presenting 'sustainable organizations'. Accounting, Organizations and Society, 39(6):477-494.

TURPIE, J.K. 2003. The existence value of biodiversity in South Africa: How interest, experience, knowledge, income and perceived level of threat influence local willingness to pay. Ecological Economics, 46(2):199-216.

VAN LIEMPD, D. \& BUSCH, J. 2013. Biodiversity reporting in Denmark. Accounting, Auditing \& Accountability Journal, 26(5):833-872.

WYNBERG, R. 2002. A decade of biodiversity conservation and use in South Africa: Tracking progress from the Rio Earth Summit to the Johannesburg World Summit on Sustainable Development: Review article. South African Journal of Science, 98(5 \& 6):233-243. 
Appendix 1: List of companies included in the analysis

\begin{tabular}{|c|c|c|c|c|c|c|}
\hline \multirow[t]{2}{*}{ Name of Company } & \multicolumn{2}{|r|}{2011} & \multicolumn{2}{|c|}{2012} & \multicolumn{2}{|r|}{2013} \\
\hline & $\begin{array}{l}\text { Integrated } \\
\text { report }\end{array}$ & $\begin{array}{l}\text { Sustainability } \\
\text { report }\end{array}$ & $\begin{array}{l}\text { Integrated } \\
\text { report }\end{array}$ & $\begin{array}{c}\text { Sustainability } \\
\text { report }\end{array}$ & $\begin{array}{l}\text { Integrated } \\
\text { report }\end{array}$ & $\begin{array}{l}\text { Sustainability } \\
\text { report }\end{array}$ \\
\hline \multicolumn{7}{|l|}{ Mining companies } \\
\hline${ }^{*}$ Glencore Plc & $\checkmark$ & $\checkmark$ & $\checkmark$ & $\checkmark$ & $\checkmark$ & $\checkmark$ \\
\hline${ }^{*}$ BHP Billiton & $\checkmark$ & $\checkmark$ & $\checkmark$ & $\checkmark$ & $\checkmark$ & $\checkmark$ \\
\hline * Anglo American PLC & $\checkmark$ & $\checkmark$ & $\checkmark$ & $\checkmark$ & $\checkmark$ & $\checkmark$ \\
\hline${ }^{*}$ Anglo American platinum & $\checkmark$ & $x$ & $\checkmark$ & $\checkmark$ & $\checkmark$ & $\checkmark$ \\
\hline * Impala platinum limited & $\checkmark$ & $\checkmark$ & $\checkmark$ & $\checkmark$ & $\checkmark$ & $\checkmark$ \\
\hline * AngloGold Ashanti & $\checkmark$ & $\checkmark$ & $\checkmark$ & $\checkmark$ & $\checkmark$ & $\checkmark$ \\
\hline * Exxaro resources & $\checkmark$ & $x$ & $\checkmark$ & $x$ & $\checkmark$ & $\checkmark$ \\
\hline * Gold Fields limited & $\checkmark$ & $x$ & $\checkmark$ & $x$ & $\checkmark$ & $x$ \\
\hline * Assore limited & $\checkmark$ & $x$ & $\checkmark$ & $x$ & $\checkmark$ & $x$ \\
\hline * African Rainbow minerals & $\checkmark$ & $\checkmark$ & $\checkmark$ & $\checkmark$ & $\checkmark$ & $\checkmark$ \\
\hline \multicolumn{7}{|l|}{ Food producers } \\
\hline *Tiger Brands imited & $\checkmark$ & $x$ & $\checkmark$ & $x$ & $\checkmark$ & $x$ \\
\hline * Pioneer Foods group limited & $\checkmark$ & $x$ & $\checkmark$ & $x$ & $\checkmark$ & $x$ \\
\hline * AVI limited & $\checkmark$ & $x$ & $\checkmark$ & $x$ & $\checkmark$ & $x$ \\
\hline * Tongaat Hulett limited & $\checkmark$ & $x$ & $\checkmark$ & $x$ & $\checkmark$ & $x$ \\
\hline * Shoprite Holding limited & $\checkmark$ & $x$ & $\checkmark$ & $\checkmark$ & $\checkmark$ & $\checkmark$ \\
\hline${ }^{*}$ Pick n Pay Stores limited ${ }^{10}$ & $\checkmark$ & $\checkmark$ & $\checkmark$ & $\checkmark$ & $\checkmark$ & $\checkmark$ \\
\hline * Spar Group limited & $\checkmark$ & $x$ & $\checkmark$ & $x$ & $\checkmark$ & $x$ \\
\hline${ }^{*}$ RCL Food limited & $\checkmark$ & $\checkmark$ & $\checkmark$ & $\checkmark$ & $\checkmark$ & $\checkmark$ \\
\hline * Oceana Group limited & $\checkmark$ & $x$ & $\checkmark$ & $x$ & $\checkmark$ & $x$ \\
\hline * Illovo Sugar limited & $\checkmark$ & $x$ & $\checkmark$ & $x$ & $\checkmark$ & $x$ \\
\hline
\end{tabular}

Of the twenty companies included in the food producer and food and drug retail sectors, 10 are included in the analysis representing 88.1 per cent of the market capitalisation. Ten of the 53 listed mining companies are included representing 95.6 per cent of the market capitalisation. 


\section{Appendix 2: Theme register}

The following table was developed using themes (codes) employed by Grabsch et al. (2012); Van Liempd and Busch (2013).

Table 1

Theme codes

\begin{tabular}{|c|c|c|c|c|}
\hline Themes & $\begin{array}{l}\text { Code } \\
\text { symbol }\end{array}$ & 2011 & 2012 & 2013 \\
\hline \multicolumn{5}{|l|}{ Scene-setting } \\
\hline Definition & A & & & \\
\hline Mission statement & B & & & \\
\hline \multicolumn{5}{|l|}{ Species related } \\
\hline Site-specific & C & & & \\
\hline Specific species & D & & & \\
\hline Surveys & $\mathrm{E}$ & & & \\
\hline IUCN Red list & $\mathrm{F}$ & & & \\
\hline \multicolumn{5}{|l|}{ Social engagements } \\
\hline Partnerships & G & & & \\
\hline Awards & $\mathrm{H}$ & & & \\
\hline Stakeholder engagements & 1 & & & \\
\hline \multicolumn{5}{|l|}{ Performance evaluations } \\
\hline Target performance & $\mathrm{J}$ & & & \\
\hline Costs & K & & & \\
\hline \multicolumn{5}{|l|}{ Risk } \\
\hline Risk & L & & & \\
\hline Risk management & M & & & \\
\hline Incidents & $\mathrm{N}$ & & & \\
\hline Materiality & $\mathrm{O}$ & & & \\
\hline \multicolumn{5}{|l|}{ Internal management } \\
\hline Biodiversity action plans & $\mathrm{P}$ & & & \\
\hline biodiversity officer & Q & & & \\
\hline \multicolumn{5}{|l|}{ External reports } \\
\hline GRI and other frameworks & $\mathrm{R}$ & & & \\
\hline
\end{tabular}

